\title{
Hedging and the Paradoxical Acquirer Announcement Effects in International Mergers
}

\author{
J. Barry Lin \\ Department of Humanities and Social Sciences \\ College of Arts and Sciences \\ Khalifa University of Science and Technology \\ Abu Dhabi, UAE
}

\begin{abstract}
This paper documents a paradoxical acquirer announcement effect: that nonhedging firms exhibit higher (more positive) announcement effect than hedging firms, contradicting earlier studies that document better valuation and performance for hedging firms. We provide evidence consistent with the idea that non-hedging firms exhibit higher information asymmetry and the higher announcement effect over the hedging firms is potentially a form of mis-pricing as a result of the higher information asymmetry.
\end{abstract}




\section{Hedging and the Paradoxical Acquirer Announcement Effects in International Mergers}

\section{INTRODUCTION}

This paper investigates US firms engaging in international acquisitions. In particular, we focus on the effect of hedging - a critical corporate operation for multinational corporations. It has been well documented that corporate hedging reduces volatility in firm cash flow. A reduction in cash flow volatility improves firm transparency as it is easier for outside investors and the financial markets to correctly value the firm, relative to a similar non-hedging firm. This increase in transparency (reduction in information asymmetry) can lead to reduced agency costs, and hence reduced diversification discount when firms engage in diversifying acquisitions. Since international mergers are subject to a higher degree of uncertainty, they provide a particularly interesting setting to investigate the relationship among corporate hedging, information asymmetry, and firm valuation.

Several theories have been proposed to support the view that, firm value is improved by the use of derivatives. ${ }^{l}$ Smith and Stulz (1985) suggest that hedging results in a convex tax function due to tax rules and regulations which generates lower expected

\footnotetext{
${ }^{1}$ The possible major categories for the positive relation between firm value and hedging are 1) convex tax function due to various tax rules and regulations leads to low expected tax liability and then high firm value (Smith and Stulz (1985)), 2) hedging lower the agency costs. Thus, such underinvestment problem can be solved (Mayers and Smith (1987)) and also hedging allows managers to reduce the noise in their signals (Breeden and Viswanathan (1996), and DeMarzo and Duffie (1995)), 3) if a firm use hedges, then costs of financial distress are reduced (Smith and Stulz (1985), 4) hedging impact on the coordination of investment and financing policies. Froot, Scharfstein, and Stein (1993) argue that high cost for additional financing induces a firm to scale back value-maximizing investments. Hedging alleviates the dependence of investment on cash flow, and firm can maximize its value, 5) for the firm size in hedging, many theoretical literatures have shown conflicting opinions. Empirical evidence suggests a positive relationship between size and the use of derivatives (e.g. Nance, Smith, and Smithson (1993)).
} 
tax liability and hence higher firm value. Mayers and Smith (1987) argue that hedging lower agency costs from underinvestment problem. Breeden and Viswanathan (1996) and DeMarzo and Duffie (1995) suggest that hedging allows managers to reduce the noise in signaling firm quality. Smith and Stulz (1985) also maintain that hedging reduces costs of financial distress. Using Tobin's Q as an approximation for firm market value, Allayannis and Weston (2001) provide significant evidence that a firm hedging with foreign currency derivatives is generally valued higher than a non-hedging firm.

For firms that are highly dependent on foreign markets or firms that operate high percentage of products or services in foreign countries, their exposure to foreign exchange (FX) risk is higher than domestic firms. Another view is that the foreign exchange hedging behavior of firms is related to their complexity. Firms with substantial foreign exposures are also more complex than purely domestic firms in terms of their informational environment. It is harder for outside investors, analysts, and the financial markets to value these firms. Stockholders monitoring the risk exposures of their own portfolios face a greater informational challenge with firms with foreign exposures (Dolde and Mishra (2004)). For these reasons, firms with greater variation in cash flows or accounting earnings resulting from exposure to foreign exchange-rate risk have greater potential benefits from using hedges. Geczy, Minton, and Schrand (1997) find that firms with extensive foreign exchange-rate exposure are more likely to use currency derivatives. Dolde and Mishra (2004) report that both the decision about whether to use foreign exchange derivatives and the decision on the extent of use are significantly related to firm complexity. 
If hedging resolves agency problems and reduces information asymmetry, firm value should increase as transparency in firm's stock price also improves. Focusing on firms with the greatest potential need and potential gain from foreign exchange risk management, we investigate announcement effect for firms engaging in international mergers.

The rest of the paper is organized as follows. The next section explains our data and methodologies. Section 3 reports empirical results. Section 4 provides concluding remarks.

\section{DATA and METHODOLOGY}

Our sample consists of public corporate acquisitions reported by the Securities Data Corporation (SDC) in their Mergers and Acquisitions database from 1992 to 1996. We include all acquisitions of non-U.S. target firms by U.S. bidder firms during this period. We collect hedging data from Database of Users of Derivatives published by Swaps Monitor Publications, Inc. Firms included in our initial sample are fortune 500 firms, Business Week 100 firms, and big size firms whose revenues are greater than $\$ 500$ millions or total assets are greater than $\$ 500$ million. Also other small hedging firms are included. In our tests, we use the amount of derivatives as well as the use of derivatives. Swap Monitor lists the notional hedging amounts about options, swaps, futures, and forwards. Corporate finance data and stock return data for sample firms are extracted from COMPUSTAT and CRSP respectively.

Table 1 reports the distribution of hedging and non-hedging firms in our sample over time and across regions. Clearly, in this sample of US firms engaging in international 
mergers, more firms practice foreign exchange hedging than not. Interestingly, North America is the only geographic region where there are more non-hedging firms than hedging firms in our sample. This may be a result of the more integrated business environment within the NAFTA framework and the close proximity, which reduces the needs to hedge for these multinational firms.

[Insert Table 1 about here]

\section{EMPIRICAL RESULTS}

\section{1 Hedging and Announcement Effect}

To gauge market response to these international acquisition announcements, we conduct standard event-study methodology. Table 2 reports ARs and CARs between 10 days before and after the announcements. On the announcement day and the following day, there are small positive and statistically significant ARs for the whole sample and for both the hedging and non-hedging firms. The differences between hedging and nonhedging firms are insignificant. Figure 1 plots CARs for the 2 groups from day -10 to day +10. There is a distinct pattern that non-hedging firms outperform hedging firms, especially from just before the announcements to 10 days after the announcements.

To further clarify the differences, Panel B of Table 2 compares CARs over different windows around the merger announcements. For the -10 to +10 window, hedgers significantly under-perform non-hedgers by a little over $1.5 \%$. The difference is a significant $1.09 \%$ for the 0 to +10 window. 
Earlier studies in mergers and acquisitions generally find an insignificant or slightly negative announcement effects for acquirer stocks ${ }^{2}$. In light of the prior evidence, our sample of non-hedging firms appears to outperform the hedging firms upon the merger announcements. This result differs from earlier findings and is quite paradoxical in light of earlier studies that document better performance of hedging firms. A number of theoretical papers argue that hedging reduces information asymmetry. Our paradoxical result might then be interpreted in the following way: the stocks of non-hedging firms experienced short-run mis-pricing, possibly due to higher degree of information asymmetry. We provide further empirical evidence on these issues in later analyses.

[Insert Table 2 about here]

[Insert Figure 1 about here]

\subsection{Measuring Information Asymmetry}

As we hypothesize that hedging reduces information asymmetry, in this section we compare hedging and non-hedging firms using 3 information variables (NAF, INSTP, and $D I S P)$ as well as a composite index of information asymmetry.

We follow Best, Hodges, and Lin (2004) and other earlier studies in using institutional ownership (INSTP) and the dispersion in analysts forecasts (DISP) as measures of information asymmetry. Institutional investors can be described as informed investors because they monitor the firms carefully and often managers have closer communication

\footnotetext{
${ }^{2}$ See, for example, Asquith (1983) and Asquith and Kim (1982), among others. Asquith, Bruner, and Mullins (1983), however, find that some bidder stocks experience substantial announcement gains which are positively related to the relative size of the targets.
} 
with institutional investors. ${ }^{3}$ Therefore, the higher the percentage ownership by institutions, the less information asymmetry should be. DISP reflects both diversity of analyst beliefs and the uncertainty (lack of precision) of analyst forecasts (see Barron, Kim, Lim and Stevens (1998)). Best, Payne, and Howell (2003), among others, use analyst coverage as a measure of information asymmetry and find that firms covered by analysts have lower information asymmetry than non-covered firms as a result of the information produced by analysts. The more a firm's earnings are forecasted by analysts, the less information asymmetry we can expect $(N A F)$.

To fully utilize all the information available from these three measures while alleviate the impact of outliers, we create an information index (INFO INDEX) by combining all three information measures used above ${ }^{4}$. We first rank each firm in the sample by the magnitude of each of the information variables above. Then we compute the average of all the ranks of the three different information measures as our information index: INFO INDEX. This composite measure has the advantage of balancing all of the information measures while incorporating all of them. Specifically, the index is constructed for each observation $i=1, \ldots, N$ as:

$I_{N F O} \operatorname{INDEX}_{i}=\frac{1}{N} \frac{1}{K} \sum_{k}^{K} \operatorname{Rank}_{k}\left(\operatorname{INFO}_{i k}\right)$

\footnotetext{
${ }^{3}$ For more discussion, see Brickley, Lease, and Smith (1988).

${ }^{4}$ See Butler, Grullon, and Weston (2004) for this methodology for creating a liquidity index by ranking 6 different liquidity measures.
} 
where $\operatorname{Rank}_{k}\left(I N F O_{i k}\right)$ is the rank function which assigns rank for each observation from least informed (less transparent) to most informed (more transparent), INFO $i k$ is the $k^{\text {th }}$ measure of information asymmetry $(N A F, I N S T P$, or inverse value of $D I S P)$ for firm $i$ in our sample, and $K$ is the dimensions of information measures. For each information variable, the firm with the least information asymmetry (the most transparency) is ranked as $N$ while the firm with the most information asymmetry is ranked as one. The denominator, $K$, averages the ranks regardless of the number of information values of the firm in the sample. For example, the firm that has only 2 information measures in records is divided by $K=2$. Firm with all three measures is divided by $K=3$. Finally, in dividing by $N$, we scale the INFO INDEX to a value between $1 / \mathrm{N}$ (least informed firm) and 1 (most informed firm).

In Table 3, while hedging firms on average have over 13 analyst earnings forecasts, non-hedging firms only have few than 10, with a statistically significant difference of almost 4. On average, the percentage institutional ownership for hedging firms is $58.68 \%$, while it is $55.44 \%$ for non-hedging firm. Although the difference of $3.24 \%$ is not large, it is statistically significant. The dispersion variable does not show significant difference between the 2 groups. The information index is significantly different, with the hedging firms exhibiting lower information asymmetry. This provides evidence that hedging firms suffer from less information asymmetry, confirming earlier studies.

With respect to firm characteristics, hedging firms possess larger free cash flow which is $3.54 \%$ of total assets, compared with $2.64 \%$ for non-hedging firms. Hedging firms are also larger and traded substantially more. 
[Insert Table 3 about Here]

\section{3 Regression Results}

Panel A of Table reports regression results for the full sample. We focus on the information variables here. All three measures of information asymmetry (INFO INDEX, NAF, INSTP) are significantly negative, indicating that higher information asymmetry (lower value of the three measures) is associated with higher CAR, confirming our earlier hypothesis that non-hedging firms exhibit more short-run over-reaction. The dispersion variable is highly significant and positive, again confirming the idea that higher information asymmetry is associated with positive short-run CAR.

Panel B of Table 4 is a regression of the hedging firms, while Panel C reports on the non-hedging firms. In contrast, all 4 information asymmetry measures are statistically insignificant for hedging firms, while NAF is significant and negative for the non-hedging firms and the dispersion variable is significantly positive for the non-hedging firms. This again gives some support to the idea that non-hedging firm experience short-run positive over-reaction due to higher information asymmetry, which the hedging firms do not exhibit.

[Insert Table 4 about Here]

In Table 5 we further investigate the relationship between high- and lowinformation asymmetry and the short-run announcement effect. We use INFO INDEX to divide firms into high-, medium-, and low-information asymmetry (i.e. the lowest $33.3 \%$, middle $33.3 \%$, and highest $33.3 \%$ of INFO INDEX). We first look at the extent of hedging 
practice among the 3 groups. $F X$ represents the usage of foreign exchange derivatives and takes 1 (0) for user (non-user). Low-information asymmetry firms use significantly more hedging. Furthermore, using four increasing sizes of windows for measuring CARs, we see in Table 5 that low-information asymmetry firms consistently exhibit lower short-run announcement effect than the high-information asymmetry firms. Given earlier studies documenting clearly better long-term performance of hedging firms (Lin, Park and Pantzalis, 2009) and that firms with better hedging policy perform better (Pantzalis, Park and Lin, 2010), the short-run higher and positive announcement effect for non-hedging firms who tend to have higher information asymmetry is clearly an effect of mis-pricing. The paradoxical announcement effect (i.e., higher positive CARs for non-hedging firms over hedging firms) can be a result of difference in information asymmetry.

[Insert Table 5 about Here]

\section{CONCLUSIONS}

While several earlier studies provide evidence that long-term performance is better for hedging firms and that firms with better hedging policy perform better, we provide evidence that the short-run announcement effect is paradoxically higher (more positive) for non-hedging firms over hedging firms. We propose that this might be a result of higher information asymmetry for non-hedging firms, and our empirical evidence provide support for this hypothesis. The paradoxical effect can be explained rationally after all. 


\section{REFERENCES}

Asquith, P., 1983, Merger Bids, Market Uncertainty and Stockholder Returns, Journal of Financial Economics 11, 51-83.

Asquith, P., Robert Brunner and David Mullins, 1983, The Gains to Bidding Firms from Merger, Journal of Financial Economics 11, 121-139.

Asquith, P. and E. Han Kim, 1982, The Impact of Merger Bids on the Participating Firms' Security Holders, Journal of Finance 5, 1209-1228.

Allayannis, G., and J. P. Weston, 2001, The Use of Foreign Currency Derivative and Firm Market Value, Review of Financial Studies 14, 243 - 276.

Barron, O., Kim, S. Lim and D. Stevens, 1998, Using analysts' forecasts to measure properties of analysts' information environment, The Accounting Review 73, 421-433.

Best, R., Charles W. Hodges and Bing-Xuan Lin, 2004, Does Information Asymmetry Explain the Diversification Discount? Journal of Financial Research 27, 235-249.

Best, R. W., J. D. Payne, and J. C. Howell, 2003, Analyst Following and Equity Offerings Subsequent to IPOs, Review of Quantitative Finance and Accounting 20, 155-168.

Breeden, D., and S. Viswanathan, 1996, Why Do Firms Hedge? An Asymmetric Information Model, Duke University Working Paper.

Brickley, J., Ronald C Lease, Clifford W Smith, 1988, Ownership Structure and Voting on Antitakeover Amendments, Journal of Financial Economics 20, 267-291.

Butler, Alexander W., Gustavo Grullon, and James P. Weston, 2005, Can Managers Forecast Aggregate Market Returns? Journal of Finance 60, 963-986.

DeMarzo, P., and D. Duffie, 1995, Corporate Incentives for Hedging and Hedge Accounting, Review of Financial Studies 8, 743 - 771.

Dolde, W., and D. R. Mishra, 2002, Firm Complexity and Foreign Exchange Derivatives Use, University of Connecticut Working Paper.

Froot, K., D. Scharfstein, and J. Stein, 1993, Risk Management: Coordinating Corporate Investment and Financing Policies, Journal of Finance 48, 1624 - 1658.

Greczy, C., B. Minton, and C. Schrand, 1997, Why Firms Use Currency Derivatives?, Journal of Finance 52, 1324 - 1354. 
Lin, B., J. Park, and C. Pantzalis, 2009, Derivative Use, Information Asymmetry and MNC Post-acquisition Performance. Financial Management 38, 631-661.

Pantzalis, C., J. Park and J. B. Lin, 2010, Corporate Hedging Policy and Equity Mispricing. Financial Review, 45, 803-824.

Mayers, D., and C. W. Smith, 1987, Corporate Insurance and the Underinvestment Problem, Journal of Risk and Insurance 54, 45 - 54.

Nance, D. R., C. W. Smith, and C. W. Smithson, 1993, On the Determinants of Corporate Hedging, Journal of Finance 48, 267 - 284.

Smith, C., and R. Stulz, 1985, The Determinants of Firms' Hedging Policies, Journal of Financial and Quantitative Analysis 20, 391 - 405. 


\section{Table 1}

\section{Annual and Geographical Number of Mergers in the Sample, 1992 to 1996}

Reported are numbers and corresponding percentages of merger during the period, 1992 to 1996. Panel A and Panel B show the numbers based on years and areas, respectively.

Panel A: Number of mergers by year.

\begin{tabular}{llll}
\hline Year & All & $\begin{array}{l}\text { Users of foreign } \\
\text { exchange derivatives }\end{array}$ & $\begin{array}{l}\text { Non-users of foreign } \\
\text { exchange derivatives }\end{array}$ \\
\hline 1992 & 50 & 34 & 16 \\
& $(11.11)$ & $(7.56)$ & $(3.56)$ \\
1993 & 90 & 64 & 26 \\
& $(20.00)$ & $(14.22)$ & $(5.78)$ \\
1994 & 82 & 49 & 33 \\
& $(18.22)$ & $(10.89)$ & $(7.33)$ \\
1995 & 118 & 57 & 61 \\
& $(26.22)$ & $(12.67)$ & $(13.56)$ \\
1996 & 110 & 60 & 50 \\
& $(24.44)$ & $(13.33)$ & $(11.11)$ \\
Total & & & \\
& 450 & 264 & 186 \\
& $(100.00)$ & $(58.67)$ & $(41.33)$ \\
\hline
\end{tabular}

Panel B: Number of mergers by area.

\begin{tabular}{llll}
\hline Area & All & $\begin{array}{l}\text { Users of foreign } \\
\text { exchange derivatives }\end{array}$ & $\begin{array}{l}\text { Non-users of foreign } \\
\text { exchange derivatives }\end{array}$ \\
\hline European & 271 & 161 & 110 \\
& $(60.22)$ & $(35.78)$ & $(24.44)$ \\
South America & 74 & 47 & 27 \\
& $(16.44)$ & $(10.44)$ & $(6.00)$ \\
North America & 51 & 24 & 27 \\
& $(11.33)$ & $(5.33)$ & $(6.00)$ \\
Asian and Pacific & 52 & 30 & 22 \\
& $(11.56)$ & $(6.67)$ & $(4.89)$ \\
Other & 2 & 2 & 0 \\
& $(0.44)$ & $(0.44)$ & $(0.00)$ \\
Total & & & \\
& 450 & 264 & 186 \\
& $(100.00)$ & $(58.67)$ & $(41.33)$ \\
\hline
\end{tabular}


Table 2

\section{Daily Abnormal Returns (ARs) and Cumulative Abnormal Returns (CARs) in Short Period: Users versus Non-users of Foreign Exchange Derivatives}

This table reports the daily abnormal return $\left(A R_{i t}\right)$ and daily cumulative abnormal return $C A R\left(t_{l}, t_{2}\right)$ around merger announcement. 120 day estimation interval $(-$ 149 to -30$)$, and 21 day window $(-10$ to +10$)$ are used. $Z$-scores, $Z_{t}$ and $Z\left(t_{1}, t_{2}\right)$, show the significance of $A R_{i t}$ and $C A R\left(t_{1}, t_{2}\right)$ by checking whether or not $S A R_{i t}$ and $C S A R\left(t_{1}, t_{2}\right)$ statistically differ from zero. Also reported are the mean difference tests of cumulative abnormal returns and the corresponding t-statistic values (in parentheses) between users and non-users of foreign exchange derivatives.

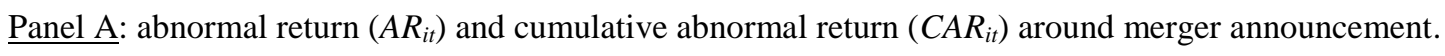

\begin{tabular}{|c|c|c|c|c|c|c|c|c|c|c|c|}
\hline \multirow[t]{2}{*}{$\begin{array}{l}\text { Event } \\
\text { Days }\end{array}$} & \multicolumn{3}{|c|}{ All $(N=450)$} & \multicolumn{3}{|c|}{ Users of $\mathrm{FX}(N=264)$} & \multicolumn{3}{|c|}{ Non-users of FX $(N=186)$} & \multicolumn{2}{|c|}{$\begin{array}{l}\text { CAR differences: } \\
\text { Users - Non-users }\end{array}$} \\
\hline & $A R s$ & $Z$-score & CARs & $A R s$ & $Z$-score & CARs & $A R s$ & $Z$-score & CARs & $\mu_{U}-\mu_{N U}$ & T-statistic \\
\hline-10 & -0.01 & -0.22 & -0.01 & -0.01 & -0.24 & -0.01 & -0.02 & -0.05 & -0.02 & 0.01 & 0.03 \\
\hline-9 & 0.09 & $2.00 * *$ & 0.07 & 0.10 & $1.84 *$ & 0.09 & 0.07 & 0.93 & 0.05 & 0.03 & 0.13 \\
\hline-8 & -0.10 & $-1.82 *$ & -0.02 & -0.19 & $-2.47 * *$ & -0.11 & 0.04 & 0.11 & 0.09 & -0.20 & -0.68 \\
\hline-7 & 0.03 & -0.03 & 0.00 & 0.12 & 1.05 & 0.01 & -0.10 & -1.30 & 0.00 & 0.02 & 0.05 \\
\hline-6 & 0.12 & 1.16 & 0.13 & 0.13 & 0.98 & 0.14 & 0.11 & 0.63 & 0.10 & 0.04 & 0.09 \\
\hline-5 & 0.07 & 0.60 & 0.19 & 0.07 & 0.46 & 0.21 & 0.06 & 0.39 & 0.17 & 0.04 & 0.10 \\
\hline-4 & 0.00 & 0.09 & 0.19 & -0.01 & -0.33 & 0.20 & 0.01 & 0.53 & 0.17 & 0.03 & 0.06 \\
\hline-3 & -0.05 & -0.62 & 0.13 & -0.08 & -0.85 & 0.11 & -0.01 & 0.05 & 0.16 & -0.05 & -0.10 \\
\hline-2 & -0.02 & 0.38 & 0.12 & -0.11 & -0.78 & 0.00 & 0.12 & 1.53 & 0.28 & -0.28 & -0.57 \\
\hline-1 & -0.08 & -1.01 & 0.03 & -0.15 & -1.55 & -0.15 & 0.01 & 0.28 & 0.29 & -0.44 & -0.82 \\
\hline 0 & 0.25 & $4.05 * * *$ & 0.28 & 0.20 & $2.44 * *$ & 0.05 & 0.32 & $3.39 * * *$ & 0.61 & -0.56 & -0.98 \\
\hline 1 & 0.29 & $4.02 * * *$ & 0.57 & 0.24 & $2.65 * * *$ & 0.29 & 0.37 & $3.10 * * *$ & 0.98 & -0.69 & -1.13 \\
\hline 2 & 0.11 & 1.08 & 0.68 & 0.04 & 0.31 & 0.32 & 0.21 & 1.31 & 1.18 & -0.86 & -1.34 \\
\hline 3 & 0.01 & -0.21 & 0.69 & -0.07 & -1.09 & 0.25 & 0.12 & 0.97 & 1.31 & -1.05 & -1.57 \\
\hline 4 & 0.03 & 0.40 & 0.72 & 0.00 & -0.03 & 0.25 & 0.08 & 0.66 & 1.39 & -1.14 & -1.61 \\
\hline 5 & 0.11 & $1.70 *$ & 0.83 & 0.08 & 1.19 & 0.33 & 0.15 & 1.23 & 1.54 & $-1.21 *$ & -1.73 \\
\hline 6 & 0.16 & $2.62 * * *$ & 0.99 & 0.07 & 1.32 & 0.40 & 0.28 & $2.51 * *$ & 1.83 & $-1.43 *$ & -1.94 \\
\hline 7 & 0.01 & -0.56 & 1.00 & 0.03 & -0.31 & 0.43 & -0.01 & -0.50 & 1.82 & $-1.39 *$ & -1.90 \\
\hline 8 & 0.08 & 0.85 & 1.08 & 0.07 & 0.79 & 0.50 & 0.09 & 0.38 & 1.90 & $-1.41 *$ & -1.86 \\
\hline 9 & -0.13 & $-1.65 *$ & 0.95 & -0.06 & -1.29 & 0.43 & -0.22 & -1.04 & 1.68 & -1.25 & -1.55 \\
\hline 10 & 0.03 & 0.88 & 0.98 & -0.08 & -0.40 & 0.35 & 0.20 & $1.85 *$ & 1.88 & $-1.52 *$ & -1.84 \\
\hline
\end{tabular}




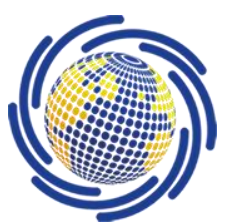

8th International Conference on Modern Research in

Management, Economics and Accounting

October 19 - 21, 2018 / Munich - Germany

$*, * *$, and $* * *$ denote significance at the $10 \%, 5 \%$ and $1 \%$ level, respectively. 
Table 2, Continued

Panel B: Cumulative abnormal returns $\left(C A R_{i t}\right)$ based on different windows.

\begin{tabular}{|c|c|c|c|c|c|c|c|c|}
\hline \multirow[t]{2}{*}{ Window } & \multicolumn{2}{|c|}{ All $(N=450)$} & \multicolumn{2}{|c|}{ Users of FX $(N=264)$} & \multicolumn{2}{|c|}{ Non-users of FX $(N=186)$} & \multicolumn{2}{|c|}{$\begin{array}{l}C A R \text { difference: } \\
\text { Users - Non-users }\end{array}$} \\
\hline & CARs & $Z$-score & $C A R s$ & $Z$-score & CARs & $Z$-score & $\mu_{U}-\mu_{N U}$ & T-statistic \\
\hline$(-1,+1)$ & $0.46 * * *$ & 4.08 & $0.28 * *$ & 2.04 & $0.70 * * *$ & 3.91 & -0.41 & -1.23 \\
\hline$(-3,+3)$ & $0.50 * * *$ & 2.91 & 0.05 & 0.43 & $1.13 * * *$ & 4.02 & $-1.08 * *$ & -2.31 \\
\hline$(-5,+5)$ & $0.71 * * *$ & 3.16 & 0.19 & 0.72 & $1.44 * * *$ & 4.06 & $-1.25 * *$ & -2.26 \\
\hline$(-10,+10)$ & $0.98 * * *$ & 2.99 & 0.35 & 0.80 & $1.88 * * *$ & 3.70 & $-1.52 *$ & -1.84 \\
\hline$(0,+1)$ & $0.54 * * *$ & 5.71 & $0.43 * * *$ & 3.60 & $0.68 * * *$ & 4.59 & -0.25 & -0.88 \\
\hline$(0,+3)$ & $0.65 * * *$ & 4.58 & $0.40 * * *$ & 2.70 & $1.02 * * *$ & 3.90 & -0.62 & -1.61 \\
\hline$(0,+5)$ & $0.80 * * *$ & 4.51 & $0.48 * *$ & 2.23 & $1.25 * * *$ & 4.35 & $-0.78 *$ & -1.78 \\
\hline$(0,+10)$ & $0.95 * * *$ & 3.97 & $0.50 *$ & 1.68 & $1.59 * * *$ & 4.18 & $-1.09 *$ & -1.81 \\
\hline
\end{tabular}




\section{Table 3}

\section{Univariate Analysis: Relationships between $C A R$ and Firm Characteristics}

This table shows the relationships between $C A R$ and firm characteristics. In Panel A, we report mean differences of information variables between users and non-users of FX. In Panel $\mathrm{B}$, we regress CAR on information variables and other characteristics. The variables examined are defined as follows. Dependent variable, $C A R(-10,+10)$, is cumulative abnormal return from 10 days prior to the announcement to 10 days after the announcement. INFO INDEX is computed as averaging the ranks in three information measures: $N A F, I N S T P$, and inverse value of DISP. NAF is the number of forecasts issued in June of MeYR $(I / B / E / S$ Summary Data). INSTP is the level of institutional ownership. DISP is dispersion (standard deviation) of one year ahead forecasts from $I / B / E / S$ summary data. $R O A$ is the ratio of net income to total assets. SIZE is the natural logarithm of sales. $T R 3 Y$ is average trading volume during last three years. FCF/TA is the free cash flow scaled by total assets.

Panel A: Mean differences of information variables between users and non-users of FX.

\begin{tabular}{llllll}
\hline & All & Users of FX & $\begin{array}{l}\text { Non-users of } \\
\text { FX }\end{array}$ & $\mu_{U}-\mu_{N U}$ & T-statistic \\
\hline INFO INDEX & 0.5026 & 0.5242 & 0.4719 & $-0.0522 * * *$ & -2.98 \\
NAF & 12.0499 & 13.6374 & 9.7263 & $-3.9111 * * *$ & -4.77 \\
INSTP & 57.3843 & 58.6760 & 55.4353 & $-3.2407 *$ & -1.88 \\
DISP & 0.0024 & 0.0023 & 0.0026 & 0.0003 & 0.55 \\
ROA & 0.0724 & 0.0703 & 0.0752 & -0.0049 & -0.82 \\
SIZE & 21.7303 & 22.1517 & 21.1366 & $1.0152 * * *$ & 7.20 \\
TR3Y & 20051.79 & 27833.93 & 9048.00 & $18785.93 * * *$ & 2.94 \\
FCF/TA & 0.0317 & 0.0354 & 0.0264 & $0.0090 *$ & 1.74 \\
\hline
\end{tabular}

$*, * *$, and $* * *$ denote significance at the $10 \%, 5 \%$ and $1 \%$ level, respectively. 


\section{Table 4}

\section{Regression: Information effect on $C A R$}

Panel A: Full Sample. Regression models controlling for information variables and other firm characteristics.

\begin{tabular}{|c|c|c|c|c|}
\hline & [1] & [2] & [3] & [4] \\
\hline INTERCEPT & $\begin{array}{l}2.5999 \\
(1.16)\end{array}$ & $\begin{array}{l}0.3947 \\
(0.17)\end{array}$ & $\begin{array}{l}1.945535 \\
(0.73)\end{array}$ & $\begin{array}{l}0.4499 \\
(0.19)\end{array}$ \\
\hline INFO INDEX & $\begin{array}{l}-5.5441 * * \\
(-2.34)\end{array}$ & & & \\
\hline$N A F$ & & $\begin{array}{l}-0.1156 * * \\
(-2.19)\end{array}$ & & \\
\hline INSTP & & & $\begin{array}{l}-0.0397 * \\
(-1.67)\end{array}$ & \\
\hline$D I S P$ & & & & $\begin{array}{l}195.5519 \text { *** } \\
(2.88)\end{array}$ \\
\hline$R O A$ & $\begin{array}{l}22.5084 \text { *** } \\
(3.45)\end{array}$ & $\begin{array}{l}23.1289 \text { *** } \\
(3.50)\end{array}$ & $\begin{array}{l}22.9819 \text { *** } \\
(3.50)\end{array}$ & $\begin{array}{l}25.1766 * * * \\
(3.79)\end{array}$ \\
\hline SIZE & $\begin{array}{l}0.0601 \\
(0.21)\end{array}$ & $\begin{array}{l}0.1623 \\
(0.54)\end{array}$ & $\begin{array}{l}0.0436 \\
(0.16)\end{array}$ & $\begin{array}{l}-0.1030 \\
(-0.38)\end{array}$ \\
\hline$T R 3 Y$ & $\begin{array}{l}-1.38 \times 10^{-5} * * \\
(-2.28)\end{array}$ & $\begin{array}{l}-1.32 \times 10^{-5} * * \\
(-2.15)\end{array}$ & $\begin{array}{l}-1.49 \times 10^{-5} * * \\
(-2.47)\end{array}$ & $\begin{array}{l}-1.53 * * \\
(-2.52)\end{array}$ \\
\hline$F C F / T A$ & $\begin{array}{l}-19.5459 * * \\
(-2.54)\end{array}$ & $\begin{array}{l}-21.6490 * * * \\
(-2.83)\end{array}$ & $\begin{array}{l}-16.9554 \\
(-2.22)\end{array}$ & $\begin{array}{l}-20.7167 * * * \\
(-2.71)\end{array}$ \\
\hline $\mathrm{N}$ & 439 & 430 & 414 & 428 \\
\hline Adjusted $\mathrm{R}^{2}$ & 0.0570 & 0.0560 & 0.0528 & 0.0634 \\
\hline F-value & $6.30 * * *$ & $6.09 * * *$ & $5.61 * * *$ & $6.78 * * *$ \\
\hline$[$ Prob $>F]$ & {$[0.0000]$} & {$[0.0000]$} & {$[0.0001]$} & {$[0.0000]$} \\
\hline
\end{tabular}




\section{Table 4, Continued}

Panel B: User firms. Regression models controlling information variables and other firm characteristics.

\begin{tabular}{|c|c|c|c|c|}
\hline & [1] & [2] & [3] & [4] \\
\hline INTERCEPT & $\begin{array}{l}-8.4528 \\
(-1.12)\end{array}$ & $\begin{array}{l}-12.5506 \\
(-1.58)\end{array}$ & $\begin{array}{l}-9.7957 \\
(-1.14)\end{array}$ & $\begin{array}{l}-9.7902 \\
(-1.23)\end{array}$ \\
\hline INFO INDEX & $\begin{array}{l}-2.9591 \\
(-0.94)\end{array}$ & & & \\
\hline$N A F$ & & $\begin{array}{l}-0.0824 \\
(-1.45)\end{array}$ & & \\
\hline INSTP & & & $\begin{array}{l}0.0085 \\
(0.25)\end{array}$ & \\
\hline$D I S P$ & & & & $\begin{array}{l}104.3753 \\
(0.68)\end{array}$ \\
\hline$R O A$ & $\begin{array}{l}9.2246 \\
(1.07)\end{array}$ & $\begin{array}{l}9.7630 \\
(1.15)\end{array}$ & $\begin{array}{l}8.5065 \\
(1.01)\end{array}$ & $\begin{array}{l}9.4070 \\
(1.05)\end{array}$ \\
\hline SIZE & $\begin{array}{l}0.4833 \\
(1.41)\end{array}$ & $\begin{array}{l}0.6467 * \\
(1.78)\end{array}$ & $\begin{array}{l}0.4615 \\
(1.30)\end{array}$ & $\begin{array}{l}0.4606 \\
(1.29)\end{array}$ \\
\hline TR3Y & $\begin{array}{l}-1.71 \times 10^{-5} * * * \\
(-2.94)\end{array}$ & $\begin{array}{l}-1.67 \times 10^{-5} * * * \\
(-2.88)\end{array}$ & $\begin{array}{l}-1.79 \times 10^{-5} * * * \\
(-3.10)\end{array}$ & $\begin{array}{l}-1.80 \times 10^{-5} * * * \\
(-3.11)\end{array}$ \\
\hline$F C F / T A$ & $\begin{array}{l}-12.3629 \\
(-1.29)\end{array}$ & $\begin{array}{l}-12.7014 \\
(-1.36)\end{array}$ & $\begin{array}{l}-13.8243 \\
(-1.45)\end{array}$ & $\begin{array}{l}-11.8246 \\
(-1.21)\end{array}$ \\
\hline $\mathrm{N}$ & 255 & 253 & 247 & 249 \\
\hline Adjusted $\mathrm{R}^{2}$ & 0.0349 & 0.0403 & 0.0331 & 0.0341 \\
\hline F-value & $2.84 * *$ & $3.12 * * *$ & $2.69 * *$ & $2.75 * *$ \\
\hline$[$ Prob $>F]$ & [0.0163] & [0.0095] & {$[0.0220]$} & [0.0194] \\
\hline
\end{tabular}




\section{Table 4, Continued}

Panel C: Non-user firms. Regression models controlling information variables and other firm characteristics.

\begin{tabular}{|c|c|c|c|c|}
\hline & {$[1]$} & [2] & [3] & [4] \\
\hline INTERCEPT & $\begin{array}{l}10.4524 \\
(0.96)\end{array}$ & $\begin{array}{l}7.5130 \\
(0.66)\end{array}$ & $\begin{array}{l}7.2130 \\
(0.70)\end{array}$ & $\begin{array}{l}11.9533 \\
1.15\end{array}$ \\
\hline INFO INDEX & $\begin{array}{l}-5.8109 \\
(-1.49)\end{array}$ & & & \\
\hline$N A F$ & & $\begin{array}{l}-0.1937 * \\
(-1.68)\end{array}$ & & \\
\hline INSTP & & & $\begin{array}{l}-0.0605 \\
(-1.57)\end{array}$ & \\
\hline DISP & & & & $\begin{array}{l}193.9942 * * \\
(2.36)\end{array}$ \\
\hline$R O A$ & $\begin{array}{l}33.3856 * * * \\
(3.29)\end{array}$ & $\begin{array}{l}35.9022 \text { *** } \\
(3.45)\end{array}$ & $\begin{array}{l}36.4828 * * * \\
(3.50)\end{array}$ & $\begin{array}{l}39.1547 \text { *** } \\
(3.79)\end{array}$ \\
\hline SIZE & $\begin{array}{l}-0.3684 \\
(-0.68)\end{array}$ & $\begin{array}{l}-0.2775 \\
(-0.50)\end{array}$ & $\begin{array}{l}-0.2335 \\
(-0.47)\end{array}$ & $\begin{array}{l}-0.6117 \\
(-1.26)\end{array}$ \\
\hline TR3Y & $\begin{array}{l}1.10 \times 10^{-5} \\
(0.28)\end{array}$ & $\begin{array}{l}1.25 \times 10^{-5} \\
(0.31)\end{array}$ & $\begin{array}{l}1.60 \times 10^{-5} \\
(0.42)\end{array}$ & $\begin{array}{l}4.55 \times 10^{-6} \\
(0.12)\end{array}$ \\
\hline$F C F / T A$ & $\begin{array}{l}-26.3828 * * \\
(-2.03)\end{array}$ & $\begin{array}{l}-27.4680 * * \\
(-2.09)\end{array}$ & $\begin{array}{l}-21.3897 \\
(-1.64)\end{array}$ & $\begin{array}{l}-29.0031 * * \\
(-2.26)\end{array}$ \\
\hline $\mathrm{N}$ & 184 & 177 & 167 & \\
\hline Adjusted $\mathrm{R}^{2}$ & 0.0779 & 0.0789 & 0.0902 & \\
\hline F-value & $4.09 * * *$ & $4.02 * * *$ & $4.29 * * *$ & \\
\hline$[$ Prob $>F]$ & [0.0015] & [0.0018] & [0.0902] & \\
\hline
\end{tabular}




\section{Table 5}

\section{Mean Differences of the Use of FX and CARs for Sub-groups Classified Based on the Level of Information Asymmetry}

This table reports means of the usage of foreign exchange derivatives and cumulative abnormal returns. Also reported are the mean difference tests and the corresponding t-statistic values between high and low information asymmetry firms. INFO INDEX is computed as averaging the ranks in three information measures: NAF, INSTP, and inverse value of DISP. Thus, high INFO INDEX indicates low information asymmetry. Each firm is classified into three groups: high, fair, and low information asymmetry (i.e. the lowest $33.3 \%$, middle $33.3 \%$, and highest $33.3 \%$ of INFO INDEX). FX represents the usage of foreign exchange derivatives and takes 1 ( 0 ) for user (non-user). $C A R\left(t_{1}, t_{2}\right)$ is cumulative abnormal returns around merger announcement where $t_{1}$, and $t_{2}$ are the lower and upper limits of event window, respectively.

\begin{tabular}{lllllll}
\hline & \multicolumn{3}{c}{ Information Asymmetry } & & \multicolumn{2}{c}{ High vs Low } \\
\cline { 2 - 3 } \cline { 6 - 7 } & High & Fair & Low & & $\mu_{\text {high }}-\mu_{\text {low }}$ & T-statistic \\
\hline FX & 0.5188 & 0.5922 & 0.6449 & & -0.1261 ** & -2.11 \\
& & & & & & \\
$C A R(-1,+1)$ & 0.8772 & 0.4946 & -0.0024 & & $0.8796 * *$ & 2.10 \\
$C A R(-3,+3)$ & 1.1229 & 0.5159 & -0.1188 & & $1.2416^{*}$ & 1.96 \\
$C A R(-5,+5)$ & 1.2231 & 0.9114 & -0.0604 & & $1.2835 *$ & 1.68 \\
$C A R(-10,+10)$ & 2.0967 & 0.9329 & -0.0277 & & $2.1244 *$ & 1.95 \\
\hline
\end{tabular}

$*$, **, and *** denote significance at the $10 \%, 5 \%$ and $1 \%$ level, respectively. 


\section{Figure 1}

Daily Cumulative Abnormal Returns to Users and Non-users of Foreign Exchange Derivatives in Short Period

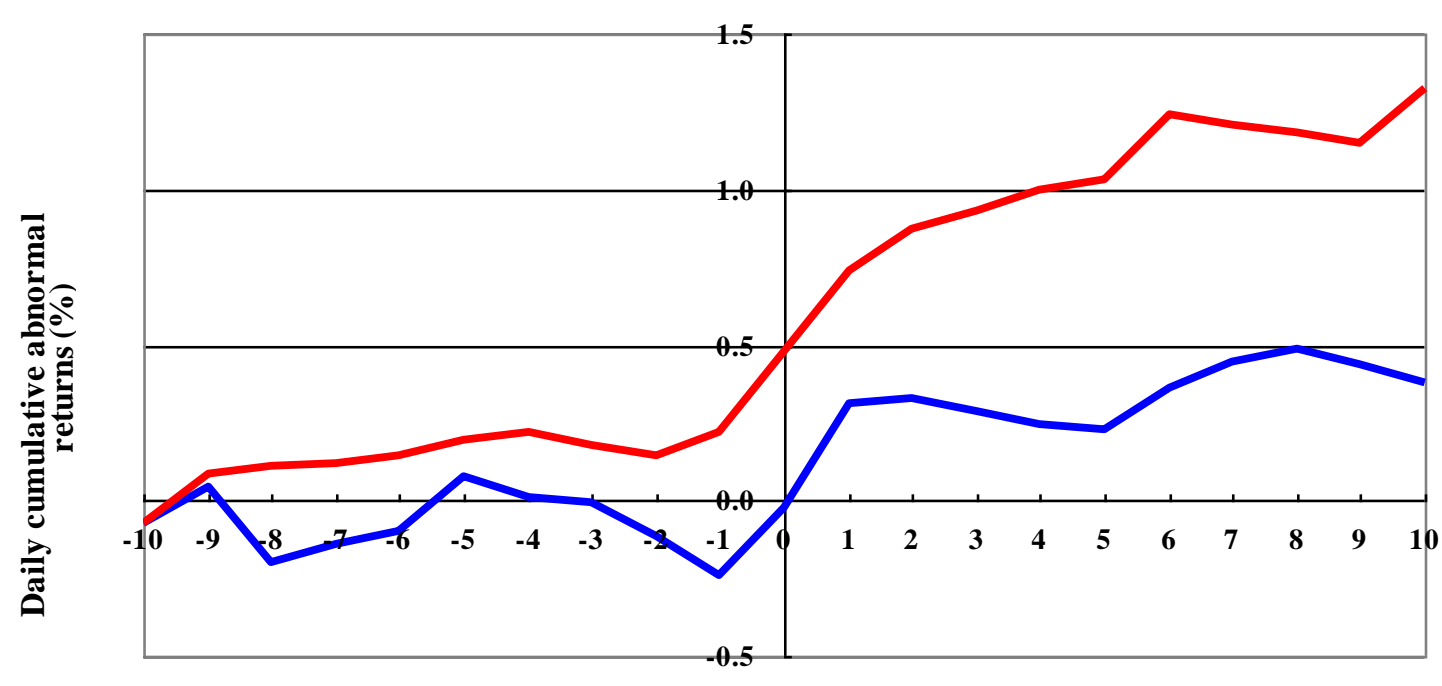

Days relative to announcement of merger

Users - Non-users 